\title{
Kamil Stepan
}

Wzmożone działania organizacyjne i mobilizacyjne polskie organizacje strzeleckie w Galicji podjęły już w 1912 r., w okresie napiętych stosunków austriacko-rosyjskich, spowodowanych trwającą wówczas wojną bałkańską. W czasie gdy część armii austriackiej została zmobilizowana wraz z wybuchem wojny europejskiej, Józef Pisłudski - który właśnie został obdarzony przez Komisję Tymczasową Skonfederowanych Stronnictw Niepodległościowych stanowiskiem komendanta głównego organizacji strzeleckich opracował podstawowe zasady ewentualnej mobilizacji.

Projektowana wówczas mobilizacja miała być podzielona na dwa „powołania”. Pierwsze miało objąć tych członków organizacji, którzy mogli zostać zmobilizowani w przeciągu 12 godzin, natomiast pozostałych członków organizacji objęło drugie ,powołanie”. Mając świadomość ówczesnej niewielkiej liczebności Związków i Drużyn Strzeleckich, Piłsudski od razu przewidywał, że jednocześnie z mobilizacją pierwszych oddziałów strzeleckich powinny zostać utworzone komisje werbunkowe, których zadaniem miało być pozyskanie nieprzeszkolonych i nieujętych dotąd $w$ ramy organizacyjne ochotników. Planowana akcja werbunkowa była jednak obwarowana różnymi zastrzeżeniami, m.in. przede wszystkim nie należało - z oczywistych względów - werbować osób będących rezerwistami armii habsburskiej.

Kolejnym ważnym osiągnięciem okresu przedwojennego było przygotowanie etatu kadrowej kompanii strzeleckiej. Etat ten powstał w roku 1913 i pozostał w mocy także podczas faktycznej mobilizacji w sierpniu następnego roku. W skład jednostki przewidzianej w ramach owego etatu wchodzili:

-1 kapitan,

-4 oficerów młodszych,

-2 sierżantów,

-1 ordynans,

- 4 plutonowych,

- 16 sekcyjnych,

- 16 starszych żołnierzy, 
- 16 sygnalistów,

- 98 szeregowców ${ }^{1}$.

Projektowane kompanie miały do pewnego stopnia być samodzielne (choć nie posiadały żadnych stanowisk kwatermistrzowskich) i zdolne do działań taktycznych, w tym do działań o charakterze partyzanckim; ewentualnie już na froncie miały być łączone w większe zgrupowania - bataliony i pułki. Po wkroczeniu na teren zaboru rosyjskiego przewidywano uzupełnienie kompanii do pełnego stanu osobowego, dzięki czemu każda z nich miałaby osiągać liczebność ok. 280 osób. Faktycznie w latach 1912-1913, kiedy to liczebność zarówno Związków Strzeleckich jak i Drużyn Strzeleckich nie przekraczała kilkuset osób w każdej organizacji, nawet mobilizacja skadrowanych, 158-osobowych kompanii natrafiłaby na wielkie trudności. Młode organizacje strzeleckie nie dysponowały ani dostateczną ilością osób przeszkolonych na kursach oficerskich, ani też nie posiadały niemal żadnych zapasów uzbrojenia i ekwipunku. W tej sytuacji w pierwszym okresie można było liczyć na zorganizowanie jedynie 2-3 kompanii kadrowych. W związku z tym jeszcze w tym samym roku został przygotowany etat „kadry kompanii kadrowej", liczącej zaledwie 64 osoby, a mianowicie:

- 1 komendanta kompanii,

- 4 komendantów plutonów,

-4 plutonowych,

-16 sekcyjnych,

- 1 podoficera gospodarczego,

- 1 podoficera sanitarnego,

-4 pionierów,

- 16 sygnalistów,

- 17 szeregowców.

Przynależeli do niej żołnierze zmobilizowani w pierwszym powołaniu „kadry kompanii”, a następnie została ona uzupełniona do etatu 158-osobowego osobami z drugiego powołania i dodatkowymi ochotnikami.

Po zażegnaniu kryzysu, w 1913 r. przejściowo napływ ochotników do organizacji strzeleckich uległ zahamowaniu, ale jeszcze w tym samym roku sytuacja uległa zmianie. W ciągu ostatniego roku przed wybuchem I wojny światowej rozwój organizacji strzeleckich był niezwykle dynamiczny. Według stanu na dzień 1 czerwca 1914 r. do Związków Strzeleckich należeć miało 7239 osób ${ }^{2}$, a Polskie Drużyny Strzeleckie z końcem roku szkolnego 1913/14 miały osiągnąć stan 5600 osób ${ }^{3}$. W tej sytuacji - przynajmniej teoretycznie - można było myśleć o wystawieniu wręcz kilkudziesięciu pełnych kompanii kadrowych.

Rzeczywistość jednak - z czego Piłsudski i jego współpracownicy doskonale zdawali sobie sprawę - była znacznie mniej optymistyczna. Przede wszystkim wśród członków organizacji strzeleckich znakomitą większość stanowili poddani austriaccy (w wy-

${ }^{1}$ J. S t a c hi e w i c z, Polskie plany mobilizacyjne przed wojna światowa, „Niepodległość” t. 8, 1933, s. 32 .

2 Ibidem, s. 45.

${ }^{3}$ H. B a g iń s k i, U podstaw organizacji wojska polskiego, Warszawa 1935, s. 735 (tu uwaga, że prawdopodobnie „stan faktyczny na dzień 1 sierpnia 1914 r. był większy przynajmniej o 1000 członków”). Według stanu ze schyłku lutego 1914 r. PDS liczyły 3997 członków (por.: J. S t a c h i e w i c z, op. cit., s. 46). 
padku Związków Strzeleckich obywatelstwo austriackie deklarowało aż 89\% członków), którzy w razie ogłoszenia mobilizacji przez Austro-Węgry musieliby stawić się w szeregach wojsk habsburskich i nie mogli być brani pod uwagę przy planowaniu mobilizacji strzeleckiej. Ponadto wśród strzelców było wielu małoletnich; za kilka lat byliby oni doskonale wyćwiczonymi kandydatami na żołnierzy, jednak do tej pory trudno było brać ich pod uwagę.

Równie źle wyglądała sprawa uzbrojenia i zaopatrzenia obu głównych organizacji. Posiadały one ledwie po kilkaset karabinów, z których tylko część była nowoczesna (karabiny powtarzalne Mannlicher M.90/95), natomiast resztę stanowiła broń przydatna właściwie jedynie do celów szkoleniowych. Według danych z czerwca $1913 \mathrm{r}$. we wszystkich ogniwach Związku Strzeleckiego było jedynie 412 karabinów, z czego 194 Mannlichery. Jeszcze gorzej wyglądało wyposażenie intendenckie, które praktycznie w ogóle wówczas nie istniało. Poszczególni strzelcy ekwipowali się na własną rękę, ale i tak podczas wszelkich ćwiczeń część występowała w strojach cywilnych. Marzeniem Piłsudskiego było, aby strzelcy mieli przynajmniej jednolite czapki, ale nawet do tego celu było daleko. Wspominany już wcześniej raport Związku Strzeleckiego z czerwca 1913 r. wykazuje, że w tym czasie w organizacjach szkolnych Związku aż $62 \%$ członków było nieumundurowanych, a w organizacjach wiejskich odsetek ten był jeszcze wyższy ${ }^{4}$. Nie inaczej było w Drużynach Strzeleckich. Był to oczywiście wynik składu organizacji strzeleckich, w których dominowała młodzież szkolna i akademicka, pozbawiona większych dochodów.

W ciągu następnego roku sytuacja uległa pewnej poprawie, zarówno dzięki staraniom samych strzelców, jak i działalności Polskiego Skarbu Wojskowego (utworzonego w okresie kryzysu bałkańskiego w 1912 r.), jednak nadal nie było szans na to, aby w razie mobilizacji udało się zwolennikom ruchu niepodległościowego samodzielnie uzbroić i wyposażyć choćby tysiąc żołnierzy.

Jeszcze inną komplikacją były stosunki z austriackimi władzami wojskowymi, które w razie wojny były skłonne wykorzystać promowany przez Piłsudskiego polski potencjał wywiadowczy, ale - ze zrozumiałych względów - wcale nie kwapiły się do dania mu wolnej ręki i popierania jego irredenty. Najistotniejsze z punktu widzenia organizacji jednostek strzeleckich zagadnienia: sprawa wyreklamowania strzelców na wypadek jednoczesnej mobilizacji strzeleckiej i austriackiej oraz zaopatrzenia Polaków w broń i ekwipunek nie zostały załatwione aż do sierpnia $1914 \mathrm{r}$.

Wybuch oczekiwanej ,wojny narodów” zastał polski ruch strzelecki w Galicji daleko od gotowości wojennej, choć poczynione w ciągu dwóch poprzednich lat przygotowania miały wkrótce zaprocentować.

2 sierpnia 1914 r. - w momencie, w którym Piłsudski otrzymał wstępnie od kpt. Józefa Rybaka „zielone światło” w sprawie organizowania jednostek strzeleckich i ich wkroczenia do Królestwa po wybuchu wojny - do dyspozycji w Krakowie znajdowali się jedynie słuchacze dwóch kursów Związku Strzeleckiego, odbywających się na Oleandrach, oraz uczestnicy kursu Drużyn, którzy zjechali z Nowego Sącza pod Wawel. Nie były to siły zbyt pokaźne. W tej sytuacji możliwe było uformowanie jedynie 2-3 kompanii, zgodnych ze 158-osobowym etatem pełnej kompanii kadrowej. Jeszcze

${ }^{4}$ J. Stachiewicz, op. cit., s. 13. 
tego samego dnia wyznaczono dowódcę dla jednej kompanii, którym został Tadeusz Kasprzycki „Zbigniew” ze Związku Strzeleckiego ${ }^{5}$.

Kompania ta - późniejsza 1 kompania kadrowa - miała „przejść granicę przed rozpoczęciem wojny i działać samodzielnie w straży przedniej innych oddziałów" wierzenie jej dowództwa Kasprzyckiemu dobrze ilustruje ówczesne problemy mobilizacyjne: na dowódcę kompanii został wybrany Kazimierz Piątek „Herwin”, który jako austriacki oficer rezerwy winien był zgłosić się do swego macierzystego pułku piechoty Landwehry. Ryzykując, że wojskowe władze austriackie uznają go za dezertera, pozostał do dyspozycji Piłsudskiego. Aby jednak nie powodować konfliktów w razie kontaktów z Austriakami, Piłsudski i Sosnkowski powierzyli dowództwo kompanii posiadającemu rosyjskie obywatelstwo Kasprzyckiemu, Piątek zaś miał wyruszyć z kompanią w charakterze dowódcy plutonu i objąć nad nią dowództwo dopiero po przekroczeniu granicy austriacko-rosyjskiej.

3 sierpnia 1914 r. na Oleandrach doszło do wielokrotnie opisywanych w literaturze wydarzeń. Pod dowództwem Stanisława Burhadta „Bukackiego” przybyła tam grupa członków Polskich Drużyn Strzeleckich, a w chwilę po niej na plac wmaszerowała grupa członków Związku Strzeleckiego i „Strzelca” pod komendą Tadeusza Kasprzyckiego. Z wybranych z obu grup żołnierzy sformowano kompanię, do której Piłsudski wygłosił krótkie przemówienie, stwierdzając m.in., iż traktuje ten pierwszy oddział strzelecki jako kadry $z$ „których rozwinąć się ma przyszła armia polska”7.

Faktycznie 1 kompania była - jak na warunki strzeleckie - jednostką doborową. Komendę plutonów objęli trzej oficerowie wywodzący się ze Związku Strzeleckiego (Kazimierz Piątek „Herwin”, Henryk Paszkowski „Krok”, Jan Kruszewski „Kruk Czarny”) oraz jeden z członków Polskich Drużyn Strzeleckich (Stanisław Burhardt „Bukacki”); wśród młodych żołnierzy wszyscy oni, choć równie młodzi, wyróżniali się doświadczeniem, mieli ukończone strzeleckie kursy oficerskie. W skład kompanii weszli wyłącznie przeszkoleni członkowie organizacji strzeleckich, jednolicie umundurowani (w siwe mundury) i uzbrojeni (w nowoczesne karabiny powtarzalne Mannlicher M. 90). Niemal wszyscy członkowie kompanii otrzymali przepisowe nabojnice, ładownice, łopatki, tornistry skórzane i koce oraz odpowiedni prowiant (chleb i konserwy).

Nie mając jeszcze ani pewności czy wojna austriacko-rosyjska wybuchnie, ani zgody dowództwa austriackiego na wkroczenie do Królestwa, Piłsudski zwlekał z wydaniem rozkazu całkowitej mobilizacji strzeleckiej. Po sformowaniu kompanii Kasprzyckiego na Oleandrach została jeszcze spora grupa strzelców, a do miasta stopniowo docierali kolejni. Tymczasem organizacja kompanii „Zbigniewa” praktycznie wyczerpała skromny zapas broni, ekwipunku i żywności, będący w dyspozycji organizacji strzeleckich w Krakowie. Ewentualne formowanie kolejnych jednostek zależało już od pomocy materialnej Austriaków. Ci jednak milczeli, czekając na rozkazy z Wiednia w sprawie tworzenia polskich oddziałów. Dopiero 3 sierpnia „,na podstawie Decyzji Najwyższej” mini-

\footnotetext{
${ }^{5}$ Literaturę na temat okoliczności powstania 1 kompanii kadrowej wykorzystał w pełni J. M. Majchrowski, zob. i de m, Pierwsza kompania kadrowa. Portret oddziału, wyd. 3 popr. i uzup., Kraków 2014, Biblioteka Centrum Dokumentacji Czynu Niepodległościowego, t. 44.

${ }^{6}$ T. K a s przy c k i, Kartki z dziennika oficera I Brygady, Warszawa 1934, s. 19.

7 J. Piłsudsk i, Przemówienie do złączonych w Kompanię Kadrowa oddziałów Związków i Drużyn Strzeleckich 3 sierpnia 1914 r. w „Oleandrach” w Krakowie, [w:] i d e m, Pisma zbiorowe, t. 4, Warszawa 1937 , s. 8.
} 
ster obrony krajowej Austrii gen. Friderich von Georgi wydał zarządzenie w tej sprawie, upoważniając dowódców obrony krajowej (Landwehry) na terenie Galicji i Bukowiny ${ }^{8}$ do ,przekształcenia tamtejszych formacji [paramilitarnych] w uzbrojone jednostki pospolitego ruszenia jak również do tworzenia w imieniu Najjaśniejszego Pana nowych takich jednostek" ". Decyzja ta umożliwiała wreszcie austriackim sztabowcom wydanie zgody na mobilizację oddziałów strzeleckich, na co tak czekał Piłsudski - choć oczywiście nie myślał on o swoich żołnierzach jako o części austriackiego Landsturmu. O ile w ówczesnej sytuacji sama decyzja ministra była poniekąd korzystna dla Komendanta Głównego, o tyle jej szczegóły (których Piłsudskiemu prawdopodobnie nie przedstawiono) były znacznie gorsze. Rozkaz gen. Georgiego zalecał uzbrajanie polskich jednostek w karabiny Werndla, stwierdzając jednocześnie, iż formacjom tym „w żadnym wypadku nie wolno wydawać karabinów wielostrzałowych"10. Jeszcze bardziej brzemienne w skutkach okazało się kolejne zalecenie ministra, nakazujące członkom tych formacji noszenie na lewym rękawie czarno-żółtych opasek; co najciekawsze, to ostatnie zarządzenie, któremu Piłsudski od początku ostro się sprzeciwiał i uważał je za hańbiące, było wydane w celu ochrony polskich żołnierzy - nosząc je, strzelcy zyskiwali prawa żołnierzy regularnych austriackich oddziałów zbrojnych, co było niezwykle istotne w razie dostania się do rosyjskiej niewoli.

Wprawdzie zarządzenia gen. Georgiego są datowane na 3 sierpnia, ale - jak się zdaje - dotarły do Krakowa dopiero 5 sierpnia. W ciągu tych trzech dni - bez wiedzy Austriaków - na Oleandrach trwała praca organizacyjna przy tworzeniu kolejnych jednostek. Ostatecznie 5 sierpnia ukończono formowanie czterokompanijnego batalionu marszowego, utworzonego - podobnie jak kompania Kasprzyckiego - z połączenia członków Polskich Drużyn Strzeleckich i Związku Strzeleckiego. W jego skład weszli również przeszkoleni już (i w większości umundurowani) członkowie obu organizacji strzeleckich; część z nich miała ukończoną szkołę żołnierską, część kurs podoficerski lub nawet oficerski. Dowództwo nad baonem objął podchorąży Drużyn Wacław Wieczorkiewicz ,Scevola"11.

W przeciwieństwie do 1 kompanii kadrowej, która ruszyła drogą wprost na Kielce, batalion „Scevoli” został tego samego dnia (6 sierpnia) skierowany do Krzeszowic. Baon wyszedł bowiem z Krakowa nieuzbrojony i dopiero w Krzeszowicach miał otrzymać karabiny i amunicję ${ }^{12}$. Struktura baonu oraz jego stan liczebny znane są z meldunku dla Komendy Głównej, sporządzonego wieczorem 6 sierpnia przez strzeleckiego komendanta placu w Krzeszowicach - Mieczysława Neugebauera „Norwida”13.

${ }^{8}$ Dowództwa Landwehry przy dowództwach 1 Korpusu (Kraków), 10 Korpusu (Przemyśl) i 11 Korpusu (Lwów).

9 S. A r s ki, J. Chu dek, Galicyjska działalność wojskowa Piłsudskiego 1906-1914, dokument nr 98, s. 616.

${ }^{10}$ Ibidem, dokument nr 99, s. 617.

${ }^{11} \mathrm{~W}$ zachowanych dokumentach z sierpnia 1914 r. swój pseudonim W. Wieczorkiewicz pisał właśnie w takiej niezbyt prawidłowej formie: „Scewola” lub „Scevola”.

${ }^{12}$ Krzeszowice zostały wybrane jako baza etapowa jeszcze przed wybuchem wojny, w okresie, gdy Piłsudski przewidywał, że jego oddziały będą działały w kierunku Zagłębia Dąbrowskiego.

${ }^{13}$ Centralne Archiwum Wojskowe w Warszawie [dalej: CAW], I.341.1.354, Wojskowe Biuro Historyczne. Odpis raportu komendy placu w Krzeszowicach do Komendy Głównej. 


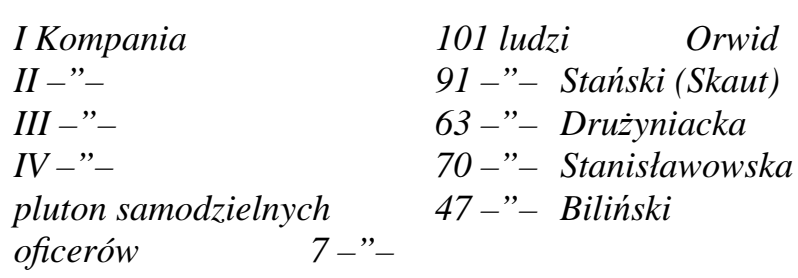

\section{9}

przyszło

385

sanitety

388

Niestety, skład kadry oficerskiej batalionu można odtworzyć tylko częściowo prócz dowódcy batalionu znani są także dowódcy kompanii oraz niektórzy oficerowie (część z nich dowodziła plutonami, reszta była przydzielona do poszczególnych kompanii à la suite). W 1 kompanii, dowodzonej przez Adama Kossakowskiego „Orwida” (ze Związku Strzeleckiego) znajdowali się: Edward Surówka „Dojan”, Stanisław Łapiński „Nilski”, Roman Dunin „Pogoń” oraz Mieczysław Ścieżyński „Wyżeł”. W 2 kompanii pod komendą Stanisława Biegańskiego „Stańskiego” (z Polskich Drużyn Strzeleckich) plutonami dowodzili: Mieczysław Mysłowski „Rawicz”, Alojzy Gluth „Nowowiejski”, niezidentyfikowany „Gryf” oraz Zygmunt Radoński „Żarski”. Spośród oficerów 3 kompanii, dowodzonej przez „Lityńskiego”, można wymienić jedynie Eugeniusza Quiriniego „Włocha” oraz Józefa Rybkę „Bożywoja”; z 4 kompanii, którą komenderował Zdzisław Trześniowski „Tatar” (ze Związku Strzeleckiego) znane są tylko pseudonimy dwóch plutonowych - „Sokoła” (prawdopodobnie był to Bolesław Grügiel) i „Kijowskiego”. Dowódcą samodzielnego plutonu był Antoni Ostrowski „Biliński” (z Polskich Drużyn Strzeleckich). Jak można wnioskować na podstawie niepełnych danych, podobnie jak w przypadku kompanii Kasprzyckiego, także w skład batalionu Wieczorkiewicza weszli przeszkoleni już członkowie obu organizacji strzeleckich.

W Krzeszowicach strzelcom ,Scevoli” wydano karabiny; fakt, że były to archaiczne Werndle, na dodatek pozbawione pasów i bagnetów, mocno wzburzył żołnierzy, których z trudem udało się uspokoić Neugebauerowi i Wieczorkiewiczowi. Trudno się zresztą dziwić - karabiny te, wprowadzone w celu uzbrojenia armii austriackiej 40 lat wcześniej, strzelały jeszcze ołowianymi pociskami z czarnym prochem (czyli prochem dymnym), zadając potworne rany i zdradzając dokładnie stanowiska strzelających. Po załagodzeniu sytuacji urządzono ćwiczenia plutonami (musztra formalna i musztra z bronią), po czym komendę batalionu objął „Norwid”. Niedługa, ledwie 40-kilometrowa droga z Krakowa do Krzeszowic dała się maszerującym mocno we znaki (według cytowanego wyżej raportu „Norwida”, 97 strzelców zameldowało „lekką niezdolność” do dalszego marszu, a pięciu kolejnych - „ciężką niezdolność”), niemniej w nieznacznie tylko uszczuplonym składzie batalion, zgodnie z otrzymanymi rozkazami, rankiem 7 sierpnia wyruszył w kolejny marsz. Drogą przez Racławice, Przeginię, Skałę i Słomniki strzelcy „Norwida" dotarli 8 sierpnia pod wieczór do Miechowa, zajętego już wcześniej przez żołnie- 
rzy 1 kompanii kadrowej. W mieście tym na żołnierzy „Norwida” czekali już Piłsudski z Sosnkowskim, którzy dotarli tam kilka godzin wcześniej.

Bezpośrednio po dotarciu do Miechowa batalion „Norwida” uległ rozformowaniu. Jego dowódca objął czasowo stanowisko komendanta placu w Miechowie, a wchodzące w skład dowodzonego przezeń batalionu kompanie całkowicie przeorganizowano. Z dotychczasowych czterech kompanii i jednego plutonu o skromnej liczebności utworzono dwie kompanie o stanach zbliżonych do wspominanego już wyżej 158-osobowego etatu strzeleckiej kompanii kadrowej. Każda z kompanii formalnie miała liczyć po 5 oficerów oraz 150 podoficerów i szeregowych w czterech plutonach po cztery sekcje. I to właśnie tym kompaniom - na równi z kompanią ,Zbigniewa” (którą, zgodnie z planem, dowodził już od przekroczenia granicy „Herwin”) - nadano miano kompanii kadrowych [podkr. K.S.]. Było to całkowicie uzasadnione nie tylko ze względu na przyjęcie przez te jednostki odpowiedniej struktury, ale także ich doborowy skład osobowy, który pod względem wyszkolenia nie ustępował kompanii sformowanej jeszcze na Oleandrach ${ }^{14}$.

Komendę 2 kompanii kadrowej, w której składzie przeważającą część stanowili członkowie Związku Strzeleckiego, objął oficer Związku, Stanisław Tessaro „Zosik”, komendantami plutonów zaś zostali: I pluton - Jerzy Sawicki „Sawa” (ZS), II pluton Antoni Ostrowski „Biliński” (PDS), III pluton - Stanisław Biegański „Stański” (PDS), IV pluton - Zdzisław Trześniowski „Tatar” (ZS).

Dowódcą 3 kompanii kadrowej, w której z kolei większość stanowili Drużyniacy, został Wacław Wieczorkiewicz „Scevola” (dowodzący batalionem podczas marszu z Krakowa do Krzeszowic), a plutony objęli: I pluton - Adam Kossakowski „Orwid” (ZS), II pluton - Mieczysław Mysłowski „Rawicz” (PDS), III pluton - Zygmunt Radoński „Żarski” (PDS), IV pluton - Mieczysław Ścieżyński „Wyżeł” (ZS). Już następnego dnia (9 sierpnia 1914 r.) zaszła zmiana na stanowisku dowódcy I plutonu, w którym „Orwida” zastąpił dotychczasowy podoficer Edward Zinth „Rzecki” (ZS). Przy IV plutonie kompanii „Scevoli” prowadzono patrol sanitarny, oraz - jako piątą sekcję tego plutonu - zawiązek oddziału technicznego (telefoniści i rzemieślnicy-specjaliści) ${ }^{15}$.

W sumie w skład obu nowych kompanii kadrowych weszło 315-320 ludzi spośród ponad 380 osób, które dotarły do Krzeszowic ze „Scevolą”. Co jednak ciekawe, we wstępie do wydanego jeszcze podczas wojny tomu relacji Legiony na polu walki ${ }^{16}$, jego redaktor, prof. Wacław Tokarz, określił łączną liczebność dwóch nowych kompanii kadrowych słowami „do 250 ludzi” - a więc ledwie do 125 osób na kompanię, znacznie poniżej oficjalnych 155 ,głów”. Także Józef M. Musiałek w swoim pisanym na gorąco opracowaniu Rok 1914 podał, że wszystkie trzy kompanie kadrowe, wyruszając 11 sierpnia z Jędrzejowa, liczyły w sumie 372 ludzi, z czego na 1 kompanię kadrową przypadać miało 132 oficerów i żołnierzy ${ }^{17}$, pozostałe dwie liczyłyby zatem jedynie

14 [S. Tes s aro] „Zo s i k”, sierż. Św is t, Historia organizacji 2 komp. III baonu 1 P[ułku] L[egionów] P[olskich], [w:] Materiały do historii I Brygady, „Żołnierz Legionów i P.O.W.” 1939, nr 3/4, s. 151; S. B or ow i c z-P o marań s k i, Historia organizacji 3/III 1 Pułku L[egionów] P[olskich], ibidem, s. 152 (materiały spisane przez różnych dowódców kompanii i batalionów w 1915 r.).

15 Dokładniejsze dane dotyczące oficerów 2 i 3 kompanii kadrowej zob.: K. S te p a n, Kompanie, którym zabrakło szczęścia, [w:] Myśl i polityka. Księga pamiątkowa dedykowana profesorowi Jackowi Marii Majchrowskiemu, red. B. S z la c h t a, t. 3, Kraków 2011, s. 129-144.

16 Legiony na polu walki. Działania Pierwszego Pułku Legionów na lewym brzegu Wisły w sierpniu i wrześniu 1914 roku. Relacye uczestników, Piotrków 1916, s. 8.

17 J. M. Musi ałek, Rok 1914. Przyczynek do dziejów Brygady Józefa Piłsudskiego, Kraków 1915, s. 45 . 
240 osób (czyli ledwie po 120 osób na kompanię). Niestety, danych tych nie można skonfrontować ze źródłami pierwotnymi, gdyż takowych prawdopodobnie w ogóle nie było; codzienne pisemne raporty stanów w oddziałach strzeleckich wprowadzono dopiero po zajęciu Kielc ${ }^{18}$.

Nie ulega jednak wątpliwości, że stany kompanii kadrowych błyskawicznie stopniały - wielu żołnierzy odkomenderowano poza macierzyste kompanie (np. do komend placu w mijanych miejscowościach), niektórzy wkrótce odeszli do innych powstających dopiero oddziałów, przede wszystkim kawalerii i artylerii, a inni, jako chorzy (głównie z odparzonymi lub otartymi nogami) pozostawali wprawdzie w stanie liczebnym kompanii, ale faktycznie nie byli zdolni do działania. W tej sytuacji wydaje się prawdopodobne, że w swym pełnym, przeszło 150-osobowym składzie, kompanie „Zosika” i „Scevoli” zebrały się tylko raz - w dniu swej organizacji w Miechowie.

9 sierpnia 1914 r., po częściowym doposażeniu (w Miechowie żołnierze Tessary i Wieczorkiewicza otrzymali pasy do karabinów i bagnety) obie kompanie wyruszyły w dalszą drogę na północ, i tego samego dnia dotarły do Książa Wielkiego, gdzie pozostały na noc. 10 sierpnia w Jędrzejowie połączyły się natomiast z 1 kompanią kadrową. Cały ich marsz (w szyku podróżnym) był znacznie mniej emocjonujący niż marsz czołowej 1 kompanii, która wraz z ułanami Władysława Prażmowskiego „Beliny” wykonywała zadania zwiadowcze i instalowała w zajmowanych miasteczkach pierwociny polskiej władzy cywilnej; jedyne poważniejsze zdanie otrzymał pluton Zygmunta Radońskiego „Żarskiego”, który jeszcze z Miechowa został detaszowany jako ochrona do ważnego tunelu kolejowego w Przysiece pod Miechowem (pluton dotarł na miejsce 9 sierpnia wieczorem).

W Jędrzejowie - gdzie znajdowała się w tym czasie też Komenda Główna Wojska Polskiego (takiej nazwy używał Piłsudski dla swego dowództwa) - doszło do prowizorycznego zorganizowania tzw. batalionu kadrowego w składzie trzech kompanii kadrowych oraz oddziału konnego „Beliny”. Tymczasowe dowództwo nad batalionem sprawował Kazimierz Piątek „Herwin”, dowodząc jednocześnie nadal 1 kompanią kadrową; w tym okresie nie doszło jednak jeszcze do utworzenia dowództwa baonu ani stałego wydzielenia elementów niebojowych (sanitariat, tabory). 11 sierpnia baon „Herwina" opuścił Jędrzejów i, przeprawiwszy się przez Nidę pod wsią Brzegi, osiągnął Chęciny i zatrzymał się na nocleg już za tym miastem, w rejonie Sitkówka-Bolechowice; w samych Chęcinach pozostawiono małą załogę, wydzieloną ze składu 1 kompanii kadrowej.

W godzinach południowych 12 sierpnia 1914 r. batalion kadrowy, poprzedzany przez kawalerię „Beliny”, wkroczył do Kielc, kończąc pierwszy etap swej wędrówki - praktycznie bez kontaktu z przeciwnikiem. Żołnierze rozkwaterowali się w rejonie dworca kolejowego, wystawiając bliskie ubezpieczenia (posterunki) na rogatkach miasta; część 2 kompanii kadrowej wyruszyła na zwiad w rejon Szydłówka, gdzie rzekomo miała się znajdować rosyjska kawaleria. Jeszcze tego samego dnia doszło w samych Kielcach i pod miastem do pierwszych utarczek strzelców z częścią rosyjskiej 14 Dywizji Kawalerii. Wprawdzie młodzi żołnierze polscy okazali się w tych drobnych starciach wygranymi, jednak ich aktywność sprowokowała rosyjskiego dowódcę, gen. Aleksandra Nowikowa, do podjęcia próby odbicia Kielc oraz okrążenia i zniszczenia oddziału

${ }^{18}$ Wyciągi z tych raportów zamieszczone zostały w aneksie. 
„,polskich sokołów”, jak Rosjanie określali oddziały Piłsudskiego. Istotnie, już przed południem 13 sierpnia Rosjanie podciągnęli na pozycję artylerię, która sprawnie wstrzelała się w cel, a jednocześnie patrole kawaleryjskie zaczęły obchodzić Kielce ze wszystkich stron, grożąc odcięciem batalionu kadrowego. W tej sytuacji sprawujący ogólną komendę w Kielcach Kazimierz Sosnkowski wydał rozkaz odwrotu. W godzinach południowych strzelcy rozpoczęli odwrót z Kielc na południe; jako ostatni miasto opuścił pluton 1 kompanii pod dowództwem „Herwina”, ostrzeliwując podążających śladem strzelców Rosjan. Ci zresztą wkrótce zaprzestali pościgu, zadowalając się zajęciem Kielc, a batalion kadrowy cofnął się w rejon Chęcin, obsadzając początkowo z dwóch stron szosę kielecką (dwoma kompaniami w pierwszej linii i jedną w odwodzie), a potem udając się na nocleg na południowy zachód od Chęcin; piechota pozostała na miejscu, natomiast kawalerię odesłano do Jędrzejowa.

W czasie gdy żołnierze kompanii kadrowych rozpoczynali swój marsz na Kielce, w Krakowie rozkręcała się mobilizacja strzelecka. 6 sierpnia 1914 r., a więc w dzień formalnego wypowiedzenia wojny Rosji przez Austro-Węgry, Piłsudski otrzymał wreszcie zgodę Austriaków na oficjalne zarządzenie mobilizacji strzelców. Jeszcze tego samego dnia został wydany „Rozkaz o powszechnej mobilizacji Strzelca, Związków i Drużyn Strzeleckich", nakazujący natychmiastową mobilizację wszystkich członków organizacji oraz ochotników w wieku powyżej 17 lat. W ciągu trzech dni (6-8 sierpnia) na Oleandrach zorganizowano 13 kompanii strzeleckich (w ogólnej sile ok. 1600 osób), które rankiem 8 sierpnia wymaszerowały z Krakowa drogą podobną do drogi baonu „Scevoli” - do Krzeszowic (gdzie zostały uzbrojone i wyekwipowane), a potem w stronę Kielc; grupa ta, pod ogólnym dowództwem Mieczysława Trojanowskiego „Ryszarda” składała się z batalionów (zgrupowań) Tadeusza Furgalskiego „Wyrwy” oraz Tadeusza Manasterskiego „Kordiana”. Rankiem 13 sierpnia - a więc w czasie, gdy baon kadrowy rozpoczynał swój krótki bój o Kielce - batalion „Wyrwy” wyruszył podwodami z Jędrzejowa do Chęcin, w rejonie których wieczorem tego dnia zetknął się z batalionem „Herwina”. Następnego dnia oba bataliony przeszły prawdziwy chrzest bojowy pod Brzegami nad Nidą, jednak główny ciężar tamtejszej walki spoczął na batalionie „Wyrwy”. Tego samego dnia dowództwo batalionu kadrowego objął Edward Rydz „Śmigły” - jeden z niewielu oficerów strzeleckich, wyreklamowanych $\mathrm{z}$ armii austriackiej. Jak wynika z zachowanych dokumentów, batalion kadrowy określano jeszcze wówczas numerem pierwszym ${ }^{19}$. Wieczorem 16 sierpnia w rejonie Milechowa i Bolmina doszło wreszcie do koncentracji gros sił strzeleckich, zarówno będących już na froncie, jak i nadciągających z Galicji. Tam też rankiem następnego dnia Józef Piłsudski wydał rozkaz reorganizacyjny, ustalający nową numerację batalionów strzeleckich, która utrzymała się - mimo licznych zmian organizacyjnych - aż do końca walk Legionów. Zgodnie z tym zarządzeniem dotychczasowy batalion I, czyli batalion kadrowy, otrzymał numer III, choć nieoficjalnie nadal używano wobec niego także określenia „batalion kadrowy”. W momencie reorganizacji batalion liczył 18 oficerów oraz 310 podoficerów i szeregowych ${ }^{20}$.

19 Por. np. rozkaz J. Piłsudskiego wydany 16 VIII 1914 o godz. 1.50 w Korzecku [w:] Legiony Polskie 1914. Wybór materiatów źródtowych z zasobu Centralnego Archiwum Wojskowego, red. A. C. Ża k, Warszawa-Kraków 2014, dok. nr 11, s. 13.

20 A. J. N a r b u t - Ł u c zy ń s k i, Historia wojenna Legionów Polskich. Powstanie i działalność bojowa Oddziału Józefa Piłsudskiego (VIII-XI 1914), Warszawa-Kraków 2014, s. 155; według zestawienia sporządzonego trzy dni później (20 VIII 1914 r., Tumlin) stan III batalionu zmienił się nieznacznie i wynosił 17 oficerów i 318 szeregowych (ibidem, s. 164). 
W pierwszych dniach po ponownym zajęciu Kielc (22 sierpnia 1914) batalion „Śmigłego” przeszedł dość poważne zmiany organizacyjne. Ponieważ bataliony strzeleckie miały mieć strukturę czterokompanijną, do batalionu wcielono - jako kompanię czwartą - kompanię dowodzoną przez Mikołaja Szyszłowskiego „Sarmata”21. Jednocześnie, podobnie jak w innych baonach, wydzielono wreszcie pododdziały nieliniowe, a więc oddział sanitarny (pod dowództwem Władysława Stryjeńskiego „Bystrama”), tabor batalionowy, utworzono też skromne dowództwo batalionu, w skład którego wchodzi dowódca batalionu Edward Rydz wraz z adiutantem Stanisławem Łapińskim „Nilskim”. Jego dzieje i walki w składzie 1 Pułku Piechoty Legionów to już całkiem odrębny temat.

Stałą, jednolitą ewidencję stanu osobowego i uzbrojenia wprowadzono w oddziale Piłsudskiego dopiero z dniem 26 VIII 1914 r. w Kielcach (wtedy też wydano specjalną instrukcję dotyczącą wypełniania formularza raportu porannego). Nie obejmuje więc ona pionierskiego okresu sprzed reorganizacji grupy strzeleckiej w Tumlinie - czyli okresu będącego tematem tego artykułu. Zarówno z okresu przed 26 sierpnia, jak i po tej dacie, w aktach 1 pułku piechoty Legionów zachowały się pojedyncze raporty 1, 2 oraz 3 kompanii kadrowej (a później także innych pododdziałów baonu) ${ }^{22}$, pozwalające ustalić ich liczebność w okresie od II połowy sierpnia do opuszczenia Kielc.

\begin{tabular}{|c|c|c|c|c|c|}
\hline \multirow[t]{2}{*}{ Data } & \multirow[b]{2}{*}{ Oficerów } & \multirow[b]{2}{*}{ Podoficerów } & \multirow[b]{2}{*}{ Szeregowych } & \multicolumn{2}{|c|}{ Stan kompanii } \\
\hline & & & & W linii & Łączny (siła) \\
\hline \multicolumn{6}{|l|}{$20 \mathrm{VIII}$} \\
\hline 21 VIII * & 5 & \multicolumn{2}{|c|}{ łącznie 150} & 155 & \\
\hline 22 VIII & 5 & \multicolumn{2}{|c|}{ łącznie 148} & 153 & \\
\hline 23 VIII & 5 & \multicolumn{2}{|c|}{ łącznie 146} & 151 & \\
\hline 25 VIII & 5 & \multicolumn{2}{|c|}{ łącznie 165} & & 170 \\
\hline 29 VIII & 5 & 19 & 139 & 163 & 169 \\
\hline $30 \mathrm{VIII}$ & 5 & 19 & 143 & 167 & 173 \\
\hline 31 VIII & 5 & 17 & 142 & 164 & 173 \\
\hline 6 IX & 5 & 18 & 135 & 158 & 173 \\
\hline 10 IX & 5 & 17 & 146 & 168 & 178 \\
\hline
\end{tabular}

* stan odtworzony na podstawie raportu z dnia następnego

${ }^{21}$ Kompania „Sarmata” (dotychczasowego komendanta krzeszowickiego obwodu Związku Strzeleckiego) została sformowana 11-12 VIII 1914 r. w Krzeszowicach z żołnierzy pozostawionych w bazie krzeszowickiej przez oddziały strzeleckie, które przemaszerowały tamtędy w poprzednich dniach na front. Kompania, początkowo nosząca numer 18 (w ciągłej numeracji kompanii strzeleckich), wymaszerowała z Krzeszowic 12 sierpnia wieczorem, by dość bezładnym marszem przez Racławice, Skałę, Miechów, Jędrzejów dotrzeć do Kielc. W nocy 20/21 VIII 1914 r. kompania dołączyła do zgrupowanych w Tumlinie głównych sił strzeleckich i po reorganizacji została następnego dnia włączona do III baonu jako jego czwarta kompania. Należy zwrócić uwagę, że kompania ta - w przeciwieństwie do pozostałych kompanii III baonu - nie uzyskała już określenia „kadrowa”.

${ }^{22}$ CAW, Akta 1 pułku piechoty Legionów Polskich, sygn. I.120.27.250. 


\begin{tabular}{|c|c|c|c|c|c|}
\hline Data & \multicolumn{5}{|c|}{ Stan kompanii } \\
\hline & Oficerów & Podoficerów & Szeregowych & W linii & Łączny (siła) \\
\hline 19 VIII * & 5 & 14 & 78 & & 97 \\
\hline 20 VIII & 5 & 14 & 78 & & 97 \\
\hline 21 VIII & 5 & \multicolumn{2}{|c|}{ łącznie 97 } & & 102 \\
\hline 22 VIII & 5 & \multicolumn{2}{|c|}{ tącznie 95 } & & 100 \\
\hline 25 VIII & 5 & \multicolumn{2}{|c|}{ tącznie 93 } & 98 & 99 [?] \\
\hline 28 VIII & 4 & 12 & 67 & 83 & 96 \\
\hline 29 VIII & 4 & 14 & 68 & 75 & 96 \\
\hline 1 IX & 4 & 12 & 59 & 74 & 96 \\
\hline 2 IX & 4 & 11 & 59 & 73 & 96 \\
\hline 3 IX & 4 & 10 & 59 & 74 & 96 \\
\hline 4 IX & 4 & 7 & 63 & 70 & 96 \\
\hline 6 IX & 4 & 7 & 59 & 80 & 87 \\
\hline 9 IX & 5 & 8 & 67 & 87 & 94 \\
\hline 10 IX & 5 & 9 & 73 & & 96 \\
\hline
\end{tabular}

* stan odtworzony na podstawie raportu z dnia następnego

\begin{tabular}{|c|c|c|c|c|c|}
\hline \multirow[t]{2}{*}{ Data } & \multirow[b]{2}{*}{ Oficerów } & \multirow[b]{2}{*}{ Podoficerów } & \multirow[b]{2}{*}{ Szeregowych } & \multicolumn{2}{|c|}{ Stan kompanii } \\
\hline & & & & W linii & Łączny (siła) \\
\hline 18 VIII * & 5 & \multicolumn{2}{|c|}{ łącznie 101} & 106 & \\
\hline $19 \mathrm{VIII}$ & 5 & \multicolumn{2}{|c|}{ łącznie 88} & 93 & \\
\hline 20 VIII & 5 & \multicolumn{2}{|c|}{ łącznie 88} & 93 & \\
\hline $21 \mathrm{VIII}$ & 5 & \multicolumn{2}{|c|}{ łącznie 88} & 93 & \\
\hline 22 VIII & 5 & \multicolumn{2}{|c|}{ łącznie 88} & 93 & \\
\hline 23 VIII & 5 & \multicolumn{2}{|c|}{ łącznie 88} & 93 & \\
\hline $26 \mathrm{VIII}$ & 5 & 13 & 56 & 74 & 81 \\
\hline 27 VIII & 5 & 13 & 58 & 76 & 80 \\
\hline $28 \mathrm{VIII}$ & 5 & 10 & 60 & 75 & 79 \\
\hline 29 VIII & 5 & 9 & 56 & 70 & 79 \\
\hline $30 \mathrm{VIII}$ & 5 & 8 & 56 & 69 & 79 \\
\hline $31 \mathrm{VIII}$ & 5 & 9 & 50 & 69 & 79 \\
\hline 2 IX & 5 & 10 & 48 & 63 & 79 \\
\hline 6 IX & 5 & 9 & 56 & 70 & 78 \\
\hline $7 \mathrm{IX}$ & 5 & 9 & 53 & 67 & 78 \\
\hline 8 IX & 5 & 9 & 55 & 69 & 78 \\
\hline 9 IX & 5 & 9 & 54 & 68 & 78 \\
\hline $10 \mathrm{IX}$ & 5 & 9 & 54 & 68 & 78 \\
\hline
\end{tabular}

* stan odtworzony na podstawie raportu z dnia następnego 
komendant kompanii -Tadeusz Kasprzycki „Zbigniew” (do 8 VIII 1914); Kazimierz Piątek „Herwin” (od 8 VIII 1914)

komendant I plutonu - Kazimierz Piątek „Herwin” (do 8 VIII 1914); Modest Słoniowski „Słoń” (od 8 VIII 1914)

komendant II plutonu - Henryk Paszkowski „Krok”

komendant III plutonu - Stanisław Burhardt „Bukacki”

komendant IV plutonu - Jan Kruszewski „Kruk Czarny”

komendant kompanii - Stanisław Tessaro „Zosik”

komendant I plutonu - Jerzy Sawicki „Sawa”

komendant II plutonu - Antoni Ostrowski „Biliński”

komendant III plutonu - Stanisław Biegański „Stański” (do 21 VIII 1914); Jan Opieliński „Tadeusz Wojszner” (od 21 VIII 1914)

komendant IV plutonu - Zdzisław Trześniowski „Tatar”

komendant kompanii - Wacław Wieczorkiewicz „Scevola”

komendant I plutonu - Adam Kossakowski „Orwid” (do 9 VIII 1914), Edward Zinth „Rzecki” (od 9 VIII 1914)

komendant II plutonu - Mieczysław Mysłowski „Rawicz”

komendant III plutonu - Zygmunt Radoński „Żarski”

komendant IV plutonu - Mieczysław Ścieżyński „Wyżeł”

Ź $\quad \mathbf{E}$

Centralne Archiwum Wojskowe w Warszawie [CAW], Wojskowe Biuro Historyczne, Odpis raportu komendy placu w Krzeszowicach do Komendy Głównej, sygn. I.341.1.354.

Centralne Archiwum Wojskowe w Warszawie [CAW], Wojskowe Biuro Historyczne, Akta 1 pułku piechoty Legionów Polskich, sygn. I.120.27.250.

Ź $\quad \mathbf{E}$

Arski S., Chudek J., Galicyjska działalność wojskowa Piłsudskiego 1906-1914, Warszawa 1967.

Bagiński H., U podstaw organizacji Wojska Polskiego 1908-1914, Warszawa 1935.

Borowicz-Pomarański S., Historia organizacji 3/III 1 Pułku L[egionów] P[olskich], [w:] Materiały do historii I Brygady, „Żołnierz Legionów i P.O.W.” 1939, nr 3/4.

Kasprzycki T., Kartki z dziennika oficera I Brygady, Warszawa 1934.

Legiony na polu walki. Działania Pierwszego Pułku Legionów na lewym brzegu Wisły w sierpniu i wrześniu 1914 roku. Relacje uczestników, Piotrków 1916.

Legiony Polskie 1914. Wybór materiałów źródłowych z zasobu Centralnego Archiwum Wojskowego, red. A. C. Żak, Warszawa-Kraków 2014.

Majchrowski J. M., Pierwsza kompania kadrowa. Portret oddziału, wyd. 3 popr. i uzup., Kraków 2014, Biblioteka Centrum Dokumentacji Czynu Niepodległościowego, t. 44. 
Musiałek J. M., Rok 1914. Przyczynek do dziejów Brygady Józefa Piłsudskiego, Kraków 1915. Narbut-Łuczyński A. J., Historia wojenna Legionów Polskich. Powstanie i działalność bojowa Oddziału Józefa Piłsudskiego (VIII-XI 1914), Warszawa-Kraków 2014.

Stachiewicz J., Polskie plany mobilizacyjne przed wojna światowa, „Niepodległość” t. 8, 1933.

Stepan K., Kompanie, którym zabrakło szczęścia [w:] Myśl i polityka. Księga pamiątkowa dedykowana profesorowi Jackowi Marii Majchrowskiemu, red. B. Szlachta, t. 3, Kraków 2011.

[Tessaro S.] „Zosik”, sierż. Świst, Historia organizacji 2 komp. III baonu 1 P[ułku] L[egionów] P[olskich], [w:] Materiały do historii I Brygady, „Żołnierz Legionów i P.O.W.” 1939, nr $3 / 4$.

\section{August 1914. From the Cadre Company to Cadre Battalion}

The article presents theoretical concepts connected with the mobilization of Polish shooting organizations in the years 1912-1914, the course of the initial phase of development of shooting troops in Kraków in early August of 1914, as well as the history, composition and staff of each of the three so-called Cadre Companies during the period of their creation at the outbreak of World War I until the reoccupation of Kielce by the troops of Józef Piłsudski.

World War I 1914-1918, Polish Legions 1914-1917, 1st Cadre Company of the Polish Legions, the Cadre Battalion of the Polish Legions, Kielce campaign of the Polish Legion 